\title{
Removing bleaching artifacts from voltage sensitive dye recordings with ICA
}

\author{
Elham Fathiazar, Gerrit Hilgen, Jutta Kretzberg ${ }^{*}$ \\ From Twenty Second Annual Computational Neuroscience Meeting: CNS*2013 \\ Paris, France. 13-18 July 2013
}

Voltage sensitive dye (VSD) imaging of multiple neurons becomes one of the most promising up-to-date methods to investigate neuronal network activity. However, optical imaging signals are often superimposed by noise and artifacts. Hence, post-processing methods are needed to overcome this corruption and separate neuronal activity from other signals. One of the significant artifacts in VSD imaging is bleaching, a decrease of the optical signal while the recorded signal of the local field potentials remains unchanged [1]. In this study we used independent component analysis (ICA) in comparison to principal component analysis (PCA) and detrend method to separate the neuronal VSD signals from bleaching artifacts. ICA is a blind source separation method that has been used in many different approaches such as to recover action potentials of neurons in multiple-detector optical recordings [3]. We used the ICA-DTU Toolbox [http://www2.imm.dtu. $\mathrm{dk} /$ pubdb/views/publication_details.php?id=4043] with maximum likelihood formulation to identify neuronal signals and the effect of bleaching.

Experimentally, we recorded from Retzius cells of an isolated midbody ganglion of the electrophysiologically well- characterized leech nervous system. VSD imaging (Figure A) based on a new VSD dye with a very good signal-to-noise ratio [2] was combined with simultaneous intracellular recording of the membrane potential (Figure B)

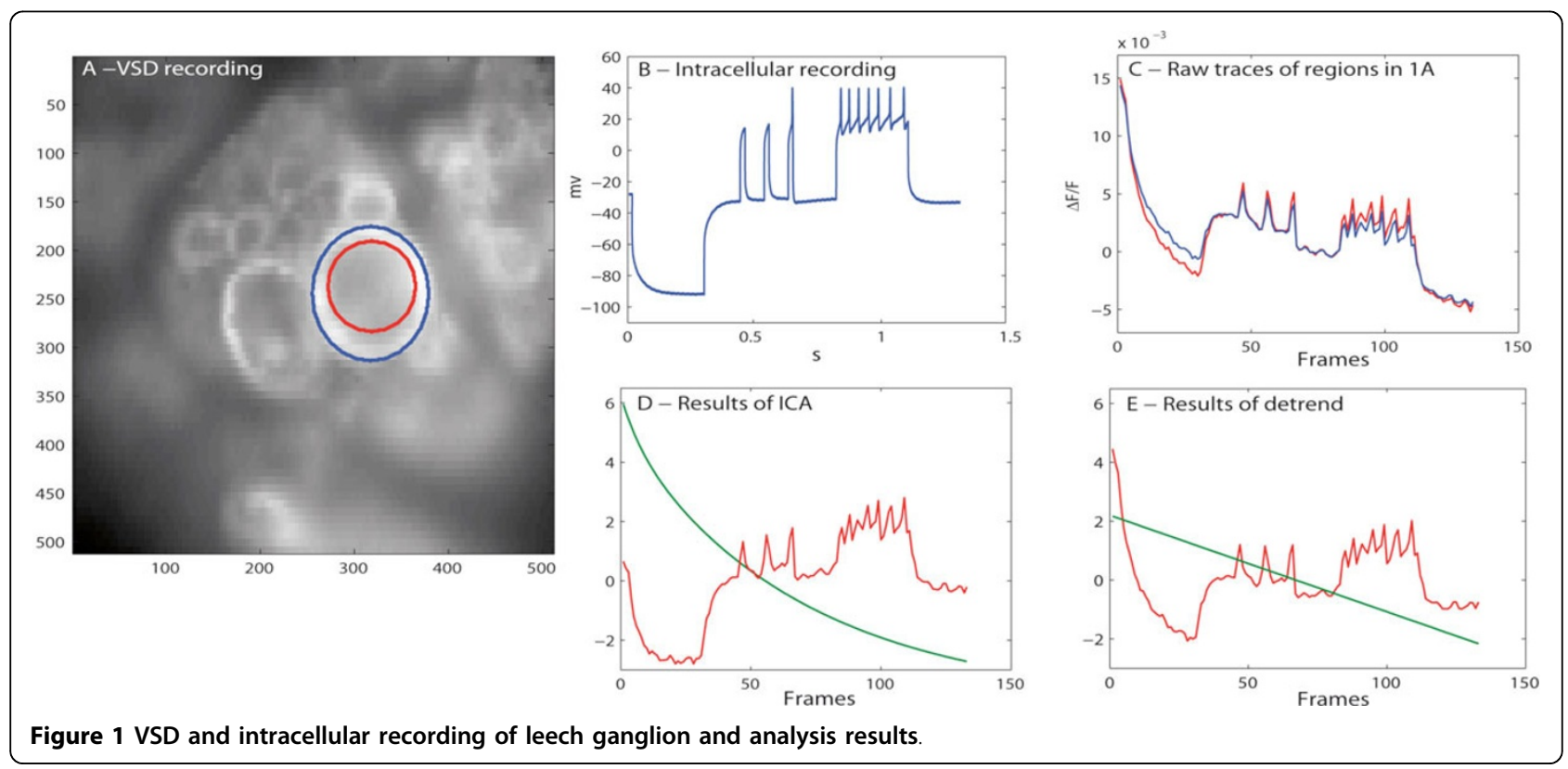

\footnotetext{
* Correspondence: jutta.kretzberg@uni-oldenburg.de

Computational Neuroscience, University of Oldenburg, Oldenburg, 26111, 
and electrical stimulation. VSD signals obtained from the region of the Retzius cell body (Figure 1A and 1C, red) and from a slightly larger region (Figure $1 \mathrm{~A}$ and $1 \mathrm{C}$, blue) were used as input signals to ICA. Of the two components returned by the algorithm one decreased exponentially, while the other resembled neuronal activity. Figure 1D shows an exponential fit of the component representing bleaching (green), and the estimated neuronal activity (red). Taking the lower sampling rate of the VSD signal $(100 \mathrm{~Hz}$ vs $10,000 \mathrm{~Hz})$ into account, this estimate reflects the dynamics of the intracellular recording (1B) well. While PCA was not able to separate bleaching from neuronal signals (not shown), the detrend method also yielded good results (Figure 1E). This method fits a piecewise linear line (1E, green) to the VSD signal, representing bleaching effect. However, the difference (1E, red) between the original trace and this line represents the graded de-and hyperpolarisations of the membrane potential seen in the intracellular recording (1B) less well than the ICA result (1D, red).

Published: 8 July 2013

\section{References}

1. Canepari M, Zecevic D: Membrane Potential Imaging in the Nervous System: Methods and Applications New York: Springer; 2010.

2. Miller EW, Lin JY, Frady EP, Steinbach PA, Kristan WB Jr, Tsien RY: Optically monitoring voltage in neurons by photo-induced electron transfer through molecular wires. PNAS 2012, 109(6):2114-2119.

3. Brown GD, Yamada S, Sejnowski TJ: Independent component analysis at neural cocktail party. Trends Neurosci 2001, 24:54-63.

doi:10.1186/1471-2202-14-S1-P222

Cite this article as: Fathiazar et al:: Removing bleaching artifacts from voltage sensitive dye recordings with ICA. BMC Neuroscience 201314 (Suppl 1):P222.
Submit your next manuscript to BioMed Central and take full advantage of:

- Convenient online submission

- Thorough peer review

- No space constraints or color figure charges

- Immediate publication on acceptance

- Inclusion in PubMed, CAS, Scopus and Google Scholar

- Research which is freely available for redistribution

Submit your manuscript at www biomedcentral.com/submit 